\title{
UNRAVELLING THE EFFECTS OF BERRY SIZE ON 'TEMPRANILLO’ GRAPES UNDER DIFFERENT FIELD PRACTICES
}

\section{DESVENDANDO OS EFEITOS DO TAMANHO DO BAGO EM UVA 'TEMPRANILLO' SOB DIFFERENTES PRÁTICAS DE CULTURA}

\author{
José M. Mirás-Avalos ${ }^{1,2}$, Ignacio Buesa ${ }^{1,3}$, Antonio Yeves ${ }^{1}$, Diego Pérez ${ }^{3}$, David Risco ${ }^{3}$, Juan R. Castel ${ }^{3}$, Diego \\ S. Intrigliolo ${ }^{1,3}$
}

\footnotetext{
${ }^{1}$ Departamento de Riego. Centro de Edafología y Biología Aplicada del Segura (CEBAS-CSIC). Campus Universitario de Espinardo, PO Box 30100, Espinardo, Murcia, Spain.

${ }^{2}$ GI-1716, Proxectos e Planificación, Dpto. Enxeñaría Agroforestal, Universidade de Santiago de Compostela, Escola Politécnica Superior de Enxeñaría, Campus Universitario s/n, 27002, Lugo, Spain.

${ }^{3}$ Instituto Valenciano de Investigaciones Agrarias (IVIA), Sustainable Agriculture Center, PO Box 46113, Moncada, Valencia, Spain.
}

* Corresponding author: Tel:: + 34968396200 ext. 6331, fax: +34 968396 213, e-mail: jose.manuel.miras.avalos@xunta.es

(Received 05.09.2018. Accepted 02.01.2019)

\section{SUMMARY}

Small berries are considered to produce the best red wines as berry size determines the skin to pulp ratio and may affect wine composition. However, contrasting results have been reported about this postulate. In this context, the aim of this work was to assess the influence of berry size on grape compositional attributes in 'Tempranillo' grapevines under different irrigation, crop load and defoliation regimes. Grapes were collected from different experiments performed during three years in a 'Tempranillo' vineyard (Valencia, Spain). Grape size distribution was assessed and several traits were measured for each size category: number of seeds, seed and skin weight, total soluble solids, titratable acidity, $\mathrm{pH}$, total phenolic index and anthocyanin concentration. Berry size exerted a significant effect on grape composition; smaller berries having higher sugars and anthocyanins concentrations. However, irrigation, crop load and defoliation also affected these compositional traits, producing greater berries with similar traits than those smaller, but coming from rain-fed and not defoliated treatments. Depending on the field practices applied, grape compositional attributes can be modulated for a given berry size. Therefore, wineries can use berry size classification for selecting those from a given size for making different wine styles.

\section{RESUMO}

Considera-se que os bagos pequenos produzem os melhores vinhos tintos, uma vez que o tamanho dos bagos determina a relação entre a película e a polpa da uva e pode afectar a composição do vinho. No entanto, resultados contrastantes foram relatados sobre este postulado. Neste contexto, o objetivo deste trabalho foi avaliar a influência do tamanho dos bagos nos atributos de composição da uva em videiras de 'Tempranillo', sob diferentes regimes de irrigação, carga e desfolhamento. As uvas foram colhidas em ensaios realizados durante três anos diferentes em um vinhedo de 'Tempranillo' (Valência, Espanha). A distribuição de tamanho de uva foi avaliada e várias características foram medidas para cada categoría de tamanho: número de grainhas, peso da grainha e da película, sólidos solúveis totais, acidez titulável, pH, índice de fenóis totais e concentração de antocianinas. O tamanho do bago exerceu um efeito significativo sobre a composição da uva; bagos menores apresentaram maiores concentrações de açúcares e de antocianinas. Porém, a irrigação, a carga e o desfolhamento também afetaram essas características de composição, produzimdo bagos de maior tamanho com características similares aos das categorías menores e provenientes de tratamentos de sequeiro e sem desfolhamento. Dependendo das práticas de campo aplicadas, os atributos composicionais da uva podem ser modulados para um determinado tamanho de bagos. Assim, as adegas podem classificar os bagos por tamanho para selecionar os de um tamanho determinado para fazer diferentes estilos de vinho.

Key words: anthocyanins, berry composition, crop load, irrigation, leaf removal, phenolics, Vitis vinifera L. Palavras-chave: antocianinas, composição do bago, carga, irrigação, desfolhamento, fenóis, Vitis vinifera L.

This is an Open Access article distributed under the terms of the Creative Commons Attribution License (http://creativecommons.org/licenses/by/4.0), which permits unrestricted use, distribution, and reproduction in any medium, provided the original work is properly cited. 


\section{INTRODUCTION}

Grapevine (Vitis vinifera L.) berry size has key implications for must composition and wine quality, mainly in red wines (Matthews and Anderson, 1988). Historically, the importance of berry size for winemaking was based on the assumption that the skin amount is relatively constant among berry sizes (Singleton, 1972). Hence, skin compounds such as anthocyanins and tannins were assumed to be more diluted in larger berries due to the lower surface area to volume ratio (Matthews and Anderson, 1988). Therefore, grape growers and oenologists believe that the lower the berry size, the better its oenological attributes are. Recently, a study found that Cabernet Sauvignon wines made from small berries presented better oenological attributes (higher total soluble solids and phenolics concentrations) than others coming from large and medium-sized berries (Gil et al., 2015). This might have implications for winemaking, since berry size affected the volatile profiles of Merlot and Cabernet (Xie et al., 2018).

However, other factors, such as crop load, vine water status and leaf surface, might affect grape oenological characteristics (Jackson and Lombard, 1993; Dai et al., 2011; Triolo et al., 2018). In fact, a number of studies contradicted the former theory that smaller berries are of better quality for winemaking; for example, an increase in skin mass proportional to berry size has been observed in Cabernet Sauvignon (Roby and Matthews, 2004) and Syrah (Barbagallo et al., 2011). Moreover, skin tannin concentrations were similar among widely different berry sizes on a per berry basis, but they did not decrease with berry size when referred to skin weight (Roby et al., 2004). Similarly, skin mass increased with berry size in Syrah (Barbagallo et al., 2011). Therefore, berry composition is not only due to berry size, but also to changes in vine metabolism caused by water status, cultural practices or annual weather conditions (Roby et al., 2004). In addition, other authors observed that Cabernet Sauvignon wines from smaller berries did not have better quality than those from larger berries (Holt et al., 2008; Calderon-Orellana et al., 2014). These findings seem to indicate that the influence of other factors such as grapevine water status, solar radiation exposure or weather conditions might play a major role on berry composition. These factors are suffering from alterations due to climate change.

In fact, climate change represents a great challenge for viticulture since grapevines are highly sensitive to atmospheric factors that alter grapevine physiology (Keller, 2010), yield (Bock et al., 2013) and wine quality (Robinson et al., 2014). In this context, climate change is an unavoidable challenge that vine growers must face in the near future (Fraga et al., 2016). According to the International Panel on Climate Change (IPCC), global temperature is expected to rise $1-5{ }^{\circ} \mathrm{C}$ over the $21^{\text {st }}$ century (IPCC, 2014). Projections also predict drier conditions in certain regions, such as southern Europe, altering the suitability of certain areas for vine growing (Fraga et al., 2016). Therefore, one of the main challenges posed by this new climate scenario is maintaining yields at a profitable level, which might be achieved by optimizing irrigation (Simmonneau et al., 2017). Finally, climate change induces alterations in grape composition, modifying wine quality and typicity; however, these alterations can be limited through adaptations in the vineyard (van Leeuwen and Destrac-Irvine, 2017).

Among these adaptations, cultural practices such as irrigation, pruning or defoliation largely influence berry size (Matthews and Nuzzo, 2007). Several studies proved that irrigation and pruning affect berry size distribution for Cabernet Sauvignon and Merlot (Holt et al., 2008; Shellie, 2010). This indicates that the way in which berry size differences are achieved is more important in determining berry composition than the actual difference in berry size. Furthermore, grapevine cultivar affects berry size due to genetic factors and most of these studies have been performed on Cabernet Sauvignon, thus, other findings may be obtained for other red cultivars (Dai et al., 2011; Houel et al., 2013).

In this context, the aim of the current study was to assess the interrelations between berry size at harvest and fresh mass distribution between seed, skin and flesh, and fruit composition in the red grapevine cultivar 'Tempranillo'. This study complements previous research were the roles of water deficit, crop load and leaf removal on fruit size and grape composition had been quantified (Intrigliolo and Castel, 2011; Risco et al., 2014) without considering the possible effect of berry size per se within each imposed treatment.

\section{MATERIAL AND METHODS}

\section{Description of the study site}

The experiment was carried out in the same 'Tempranillo' vineyard (Vitis vinifera L.) planted in 1991 on 161-49C rootstock were previously reported irrigation and canopy management trials were carried out (Intrigliolo and Castel, 2011; Risco et al., 2014). In the previous manuscripts, a detailed explanation of the vineyard characteristics is given. 
At the experimental site, the average annual rainfall (2001-2012) is $430 \mathrm{~mm}$ of which about $65 \%$ falls during the dormant period. In addition, the thermal sum (base $10^{\circ} \mathrm{C}$ ) from 1 April to 31 October is 1669 ${ }^{\circ} \mathrm{C}$ and the heliothermal index is $2291{ }^{\circ} \mathrm{C}$. During the growing seasons in which the experiments reported here were carried out (2004, 2005 and 2008), potential evapotranspiration ranged from 778 to 798 mm (Table I). The year 2005 was very dry, with annual rainfall $35 \%$ lower than the long-term average for the site, whereas 2004 and 2008 had rainfall slightly over this long-term average (Table I).

\section{TABLE I}

Rainfall, reference evapotranspiration $\left(\mathrm{ET}_{\mathrm{o}}\right)$ and irrigation depth for the growing season (1 April to 30 September) of each experimental year $(2004,2005$ and 2008)

Precipitação, evapotranspiração de referencia $\left(E T_{o}\right)$ e irrigação aplicada para o periodo de crescimento (1 de abril a 30 de setembro) de cada ano experimental (2004, 2005 e 2008).

\begin{tabular}{c|c|c|c|c}
\hline Year & $\begin{array}{c}\text { Growing } \\
\text { season } \\
\mathbf{E T}_{\mathbf{0}} \\
\mathbf{( m m )}\end{array}$ & $\begin{array}{c}\text { Growing } \\
\text { season } \\
\text { rainfall } \\
(\mathbf{m m})\end{array}$ & $\begin{array}{c}\text { Annual } \\
\text { rainfall } \\
(\mathbf{m m})\end{array}$ & $\begin{array}{c}\text { Irrigation } \\
\text { depth } \\
(\mathbf{m m})\end{array}$ \\
\hline 2004 & 798 & 228 & 521 & 82 \\
2005 & 778 & 136 & 280 & 155 \\
2008 & 780 & 468 & 491 & 130 \\
\hline
\end{tabular}

\section{Experimental setup}

The results from three different experiments, dealing with irrigation and canopy management practices, are described in the current report. Further details on these experiments (water relations, vegetative growth and yield) can be found elsewhere (Intrigliolo and Castel, 2008, 2011; Risco et al., 2014), where the effects of the different treatments were deeply analysed regardless of the berry size component.

Crop level and irrigation trial carried out in 2004. Four treatments, with three replications each, were established in a randomized-block design. The treatments were: a) Rain-fed (R) with a medium crop level (20.8 clusters/vine); b) Irrigated (I) applying $100 \%$ crop evapotranspiration $\left(\mathrm{ET}_{\mathrm{c}}\right)$ from anthesis till veraison and $50 \% \mathrm{ET}_{\mathrm{c}}$ from veraison to harvest, with a medium crop level (21.9 clusters/vine); c) Low crop load (L), irrigated as I but with 12 clusters/vine; and d) High crop load $(\mathrm{H})$, irrigated as I but with 33 clusters/vine. The $\mathrm{ET}_{\mathrm{c}}$ was estimated as the product of reference evapotranspiration $\left(\mathrm{ET}_{\mathrm{o}}\right)$, calculated according to Allen et al. (1998), and a crop coefficient $\left(\mathrm{K}_{\mathrm{c}}\right)$ that varied depending on the phenological stage of the grapevines. From June to July, $\mathrm{K}_{\mathrm{c}}$ gradually increased from 0.08 to 0.40 . After veraison, the objective was to induce a moderate soil water deficit, therefore the water amounts applied were 0.2 of $\mathrm{ET}_{0}$ (Intrigliolo and Castel, 2008). In 2004, the total irrigation depth was $82 \mathrm{~mm}$. Crop level was adjusted by shoot thinning in mid-May, leaving 13-14 shoots per vine in the $\mathrm{L}$ treatment, while no shoot thinning was carried out for $\mathrm{H}$. Each plot consisted of five rows with nine vines per row and the surrounding perimeter vines were guards (Intrigliolo and Castel, 2008).

Crop level and irrigation trial performed in 2005. The irrigation treatment consisted of applying water at $50 \% \mathrm{ET}_{\mathrm{c}}$ from anthesis to veraison and then $35 \% \mathrm{ET}_{\mathrm{c}}$ from veraison to harvest $\left(\mathrm{K}_{\mathrm{c}}\right.$ increased from 0.16 to 0.70 from June to July, total irrigation depth was 155 $\mathrm{mm}$ over the growing season). Crop level treatments had 11 (Low, L), 20 (Medium, M), and 27 (High, H) clusters per vine. In the rain-fed treatment only the $\mathrm{M}$ crop level was studied. Crop level was adjusted by shoot thinning in mid-May and by additional cluster removal in early June if needed. Each plot consisted of five rows with nine vines per row and the surrounding perimeter vines were guards. The experiment was laid out in a generalized incomplete factorial block design with three blocks and two replicated combinations per block for the irrigated treatments and a single replicate per block for the rain-fed treatment (Intrigliolo and Castel, 2011).

Defoliation trial: conducted in 2008. The treatments applied were: a) Control - undefoliated; b) ED - All leaves of the first six nodes were removed just before flowering; c) LD - late defoliation, as the former one but applied at fruit-set; and d) EED - east ED, leaf removal was applied just before flowering but only the leaves facing east of the eight first nodes were removed. In the ED and EED treatments, leaves were removed on 29 May, whereas in the LD treatment, leaves were removed on 17 June (Risco et al., 2014). Each treatment consisted of 16 vines randomly chosen within the vineyard. Irrigation $\left(50 \% \mathrm{ET}_{\mathrm{c}}\right.$ from anthesis to veraison and $35 \% \mathrm{ET}_{\mathrm{c}}$ from veraison to harvest, amounting $130 \mathrm{~mm}$ over the growing season) and crop load (27-29 clusters per vine) were the same for all treatments (Risco et al., 2014).

\section{Berry sampling and processing}

Three clusters per plant from four vines per treatment were collected at harvest. Berries were manually separated from the pedicel. Approximately 1600 berries per treatment were individually weighed in order to obtain the distribution of berry fresh weight per treatment. From this, four size categories were established, representing the four quartiles of the weight distribution. 
In the trials of 2004 and 2005, from each size category, 10 berries were randomly selected, their equatorial diameter was measured and skin and seeds were separated. For doing this, berries were sliced in half with a razor blade. Skin was obtained by carefully removing seeds and mesocarp from each berry-half using a small metal spatula and avoiding rupturing of pigmented hypodermal cells. The seeds were carefully separated from remnants of flesh by hand. Both skin and seeds were rinsed in deionised water and weighed after blotting off the excess of water. These analyses were not performed in 2008 due to limited manpower for the fieldwork.

\section{Laboratory determinations}

From each size category within each replicate (four repetitions per treatment and berry size category); 50100 berries were randomly sampled for chemical analyses. Berries (including skin and seeds) were weighed and crushed with a Thermomix blender and hand-pressed through a metal-screen filter. Then, juice was centrifuged at $17608 \mathrm{x}$ g for 10 minutes. Total soluble solids (TSS) were determined using a digital refractometer (PR-32, Atago Co. Ltd., Japan). Juice $\mathrm{pH}$ and titratable acidity (TA) were determined using an automatic titrator (Metrohm, Herisau, Switzerland)

In 2004 and 2005, total phenolic index (TPI) was determined by spectrophotometry on berry homogenates and expressed in terms of absorbance units (AU); anthocyanins (OD520 in $\mathrm{HCl}$ media, expressed in malvidin equivalents) were also determined by spectrophotometry (Ribereau-Gayon et al., 2000). In 2008, total anthocyanins and TPI were determined by ultraviolet/visible spectrophotometry in samples of 150 berries homogenized (Ultraturrax T25) to a grape paste (Iland et al., 2004). Maceration was not carried out in any of these cases. All determinations were performed in duplicate for each treatment and berry size category.

\section{Statistical analysis}

The normality of the berry weight distribution was assessed using the Kolmogorov-Smirnov test. Differences among treatments were assessed using ANOVA and the Tukey's test at $p<0.05$. For the compositional attributes and the skin and seed traits, averages for each treatment were calculated as the mean of the values among all size categories, since the number of berries used in each replicate was the same and did not depend on the berry size distribution. Since the treatments imposed in the field exerted a significant influence on berry maturation, altering the concentrations of metabolites in the grape, we accounted for this fact by using TSS as a covariate in the statistical analysis and adjusted means were calculated for each attribute to a given value of TSS (22.7 ${ }^{\circ}$ Brix). Consequently, the differences among treatments are reduced and we can hypothesize that these differences are caused by berry size. Relations between berry size and the different studied attributes were assessed through linear regression analysis and the regression coefficient $\left(\mathrm{R}^{2}\right)$ was calculated. The differences in slopes and intercepts of the fitted lines were assessed through an analysis of covariance (ANCOVA). All statistical analyses were performed using IBM SPSS Statistics for Windows, Version 20.0. (IBM Corp., Armonk, NY).

\section{RESULTS AND DISCUSSION}

\section{Berry distribution in size categories}

According to the Kolmogorov-Smirnov test, berry size followed a normal distribution in all treatments in 2004 and 2005 (p-values ranging from 0.09 to 0.77 ), whereas in the defoliation experiment carried out in 2008 , berry size distribution did not follow a normal distribution in some treatments ( $\mathrm{p}$-values $<0.001$ ). The smallest berries occurred in 2005 and, thus, size categories corresponded to lighter berries than in the other experimental years. In 2004 and 2008, berry size categories were similar (Table II). The percentages of berries within the middle size classes accounted for $70-80 \%$ of the total, except for the defoliated treatments (Table II). The treatments imposing limitations to photo-assimilate supply increased the proportion of berries in the lower size category. The fact that 2005 was less rainy than 2004 and 2008 (Table I) led to smaller berries in that year (Table II)

\section{Skin and seed distribution according to berry size}

In 2004 and 2005, seeds of 'Tempranillo' grapes accounted for $2-6 \%$ of berry weight, whereas skin represented between $9-16 \%$ of total berry mass. These percentages depended on the berry size but also on the irrigation and crop load treatments. In both experimental years, skin weight, seed number and seed weight significantly increased with berry size (Figures 1a and 1d); however, the slope of the fitted regression lines was different depending on the treatment. Skin weight per berry was strongly and positively correlated $\left(\mathrm{R}^{2} \geq 0.93\right)$ with berry size in both years, except for the irrigated (L) treatment in 2005 (Figure 1d), and it increased more than 200\% from the smallest to the largest categories. Seed number was one for small berries and increased up to 
four seeds per berry in the largest-size category (Figures $1 \mathrm{~b}$ and $1 \mathrm{e}$ ). However, the variability in this number increased with berry size independently of the treatment (Figures $1 \mathrm{~b}$ and 1e). Finally, seed weight (Figures 1c and 1f) increased with berry weight in both years.

\section{TABLE II}

Berry weights (g) corresponding to the different size categories (A, B, C and D) for each treatment and year. The percentages of berries from each category and treatment are displayed. Low, medium and high crop loads are abbreviated as L, M and H, respectively. ED = early defoliation; LD $=$ late defoliation; EED = early defoliation on the east side of the vine rows.

Peso de bagos ( $g$ ) correspondentes às diferentes categorías de tamanho (A, B, C e D) para cada tratamento e ano. As percentagens de bagos de cada categoría e tratamento são mostradas. Cargas baixa, media e alta são abreviadas como $L, M$ e $H$, respectivamente. ED = desfolhamento precoce; $L D=$ desfolhamento tardio; $E E D=$ desfolhamento precoce no lado leste das linhas de videira.

\begin{tabular}{l|c|c|c|c}
\hline & \multicolumn{5}{|c}{ Size categories } \\
\hline Treatment & A & B & C & D \\
\hline
\end{tabular}

Irrigation and crop level experiment in 2004

\begin{tabular}{l|c|c|c|c}
\hline All treatments & $<1.55$ & $1.55-2.35$ & $2.36-3.15$ & $>3.15$ \\
\hline Rain-fed (M) & 15.3 & 51.5 & 30.0 & 3.2 \\
\hline Irrigated (L) & 8.2 & 36.1 & 44.1 & 11.5 \\
\hline Irrigated (M) & 8.8 & 41.9 & 40.7 & 8.7 \\
\hline Irrigated (H) & 18.6 & 50.4 & 28.8 & 2.3 \\
\hline
\end{tabular}

Irrigation and crop level experiment in 2005

\begin{tabular}{l|c|c|c|c}
\hline \multirow{2}{*}{ Rain-fed (M) } & $<0.9$ & $0.9-1.3$ & $1.3-1.7$ & $>1.7$ \\
\cline { 2 - 5 } & 20.1 & 48.9 & 27.1 & 3.9 \\
\hline \multirow{2}{*}{ Irrigated (L) } & $<1.55$ & $1.5-2.3$ & $2.3-3.1$ & $>3.1$ \\
\cline { 2 - 5 } & 21.2 & 43.3 & 30.4 & 5.1 \\
\cline { 2 - 5 } Irrigated (M) & $<1.3$ & $1.3-1.9$ & $1.9-2.5$ & $>2.5$ \\
\hline \multirow{2}{*}{ Irrigated (H) } & 14.9 & 38.2 & 38.6 & $>2.3$ \\
\cline { 2 - 5 } & $<1.3$ & $1.3-1.9$ & $1.9-2.5$ & 7.8 \\
\hline
\end{tabular}

Defoliation experiment in 2008

\begin{tabular}{l|c|c|c|c}
\hline All treatments & $<1.65$ & $1.65-2.35$ & $2.35-3$ & $>3$ \\
\hline Control & 24.7 & 45.7 & 23.5 & 6.0 \\
\hline ED & 36.2 & 42.3 & 11.2 & 10.3 \\
\hline LD & 44.8 & 39.2 & 0.4 & 15.6 \\
\hline EED & 36.7 & 42.9 & 10.9 & 9.5 \\
\hline
\end{tabular}

\section{Berry composition: effects of treatments and relations with berry size}

Grape chemical composition parameters as function of berry size for each treatment depended on the experiment; therefore, they are described separately.

Crop level and irrigation trial (2004):

The irrigation and crop level regimes had a major effect on berry composition, with significant differences detected for all the attributes considered in this experiment (Table III). The treatments that imposed a sink-source limitation (rain-fed and high load treatments) showed lower TSS and anthocyanins concentrations. The interval of TSS ranged between
20.9 (for the high load treatment) and 24.9 (for the low load treatment) ${ }^{\circ}$ Brix. Despite this large range, a significant effect of berry weight on TSS across the berry size categories was observed for all the treatments, except for high load (Table III). Moreover, significantly higher TSS was detected for the smallest berries than for the other categories in all the treatments except for the high crop load (Table III).

On the contrary, $\mathrm{pH}$ did not show a clear trend with berry size (Table III). However, titratable acidity significantly increased with berry size (Table III), although no trend was observed when values were adjusted by TSS. Total phenolic index did not significantly vary with berry size for the studied 
treatments (Table III). Anthocyanins concentration tended to reduce with berry size, even when adjusted by TSS (Table III).

Crop level and irrigation trial (2005):

The trends observed in 2004 were similar in 2005. Smaller berries presented a significantly higher TSS content than the rest of the four size classes (Table
IV). In contrast, $\mathrm{pH}$ did not vary with berry size, except for the irrigated treatment with low load (Table IV). Titratable acidity increased with berry size, but this trend was not clear when values were adjusted for TSS (Table IV). Color attributes showed a decreasing trend with berry size (Table IV). However, in the case of TPI, this declining was not clear when values were adjusted for TSS.
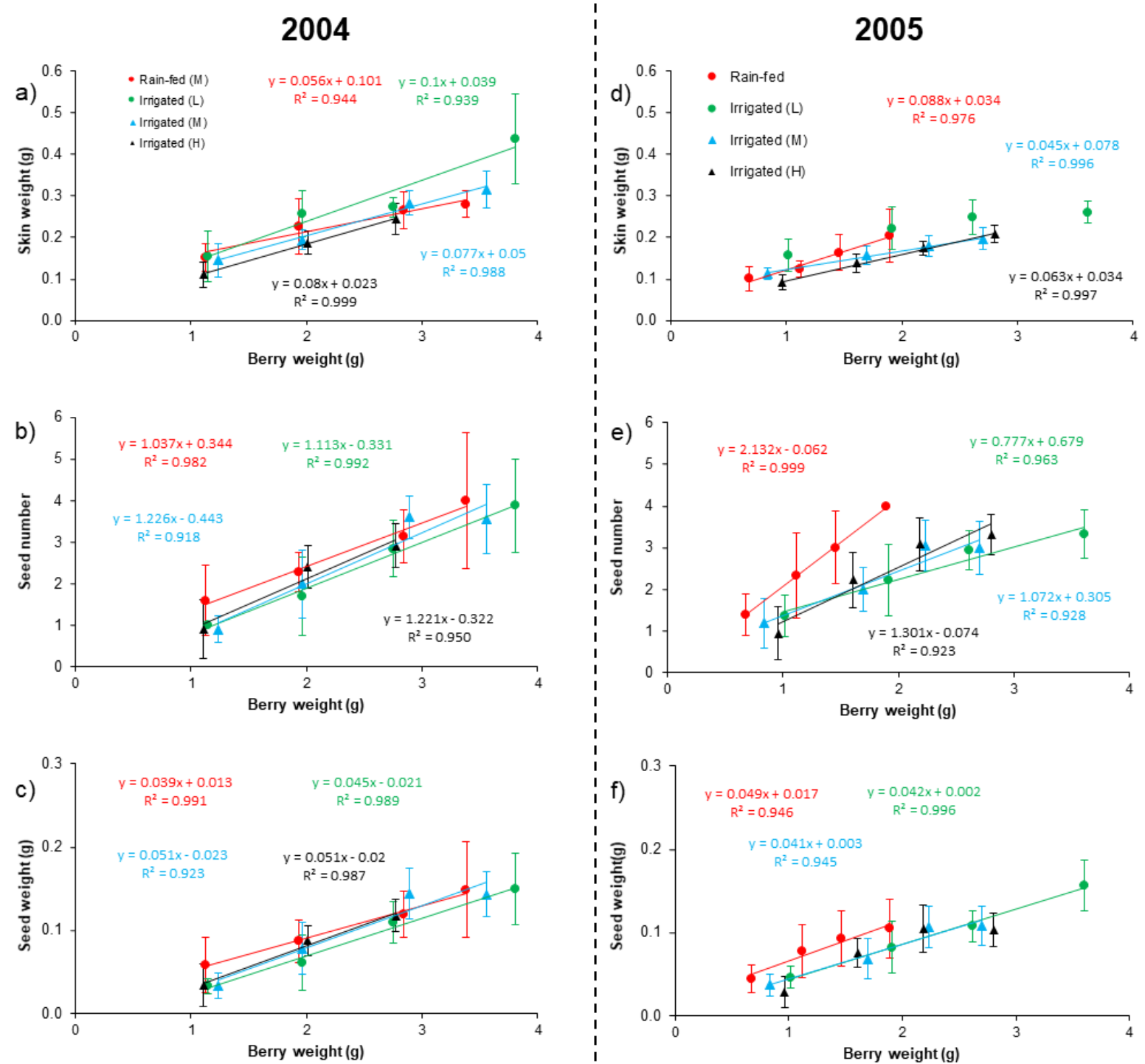

Figure 1. Skin weight, seed number and seed weight in the four different berry size categories from 'Tempranillo' grapes exposed to rain-fed and irrigation conditions, and several crop loads during the 2004 and 2005 growing seasons. Error bars indicate standard errors $(\mathrm{n}=10)$. The linear regression lines and equations between the different parameters and the average berry weight for each category and treatment are shown. Only significant regressions are depicted.

Peso da película, número de grainhas e peso das grainhas nas quatro diferentes categorias de tamanho de bagos de uva de 'Tempranillo' expostos a condições de irrigação e sequeiro, e várias cargas durante as vindimas de 2004 e 2005 . Barras de erro indicam erros padrão ( $n=10)$

As linhas de regressão linear e as equações entre os diferentes parâmetros e o peso médio dos bagos para cada categoría de tamanho e tratamento são mostrados. Apenas regressões significativas são mostradas. 


\section{TABLE III}

Berry fresh weight, total soluble solids, $\mathrm{pH}$, titratable acidity, total phenolic index and anthocyanins concentration in different sized berries (A, B,

$\mathrm{C}$ and D) from the different treatments considered in the irrigation and crop level experiment of 2004. Adjusted means after using ${ }^{\circ} \mathrm{Brix}$ as a covariate are shown between parentheses. Low, medium and high crop loads are abbreviated as L, M and H, respectively.

Peso fresco de bago, sólidos solúveis totais, pH, acidez titulável, indice de fenóis totais e concentação de antocianinas em bagos de diferentes tamanhos $(A, B, C$ e D) de cada tratamento considerado no ensaio de irrigação e nível de carga de 2004. As médias ajustadas após o uso de Brix como covariável são apresentadas entre parênteses. Cargas baixa, media e alta são abreviadas como L, Me H, respectivamente.

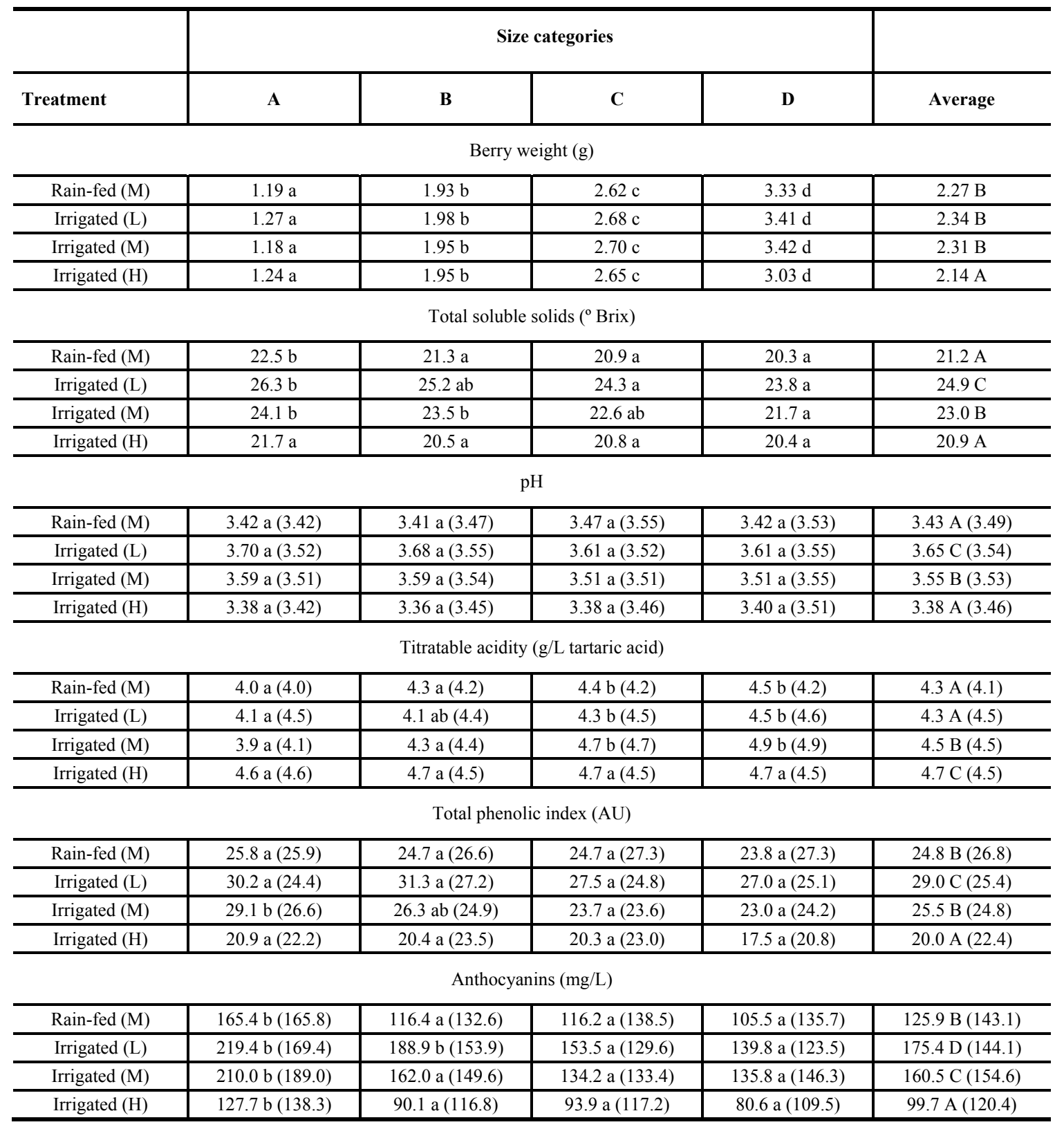

Different small letters in the row indicate significant differences $(p<0.05)$ among berry size classes. Different capital letters in the column indicate significant differences $(p<0.05)$ among treatments for the averaged attribute.

Letras minúsculas diferentes na linha indicam diferenças significativas $(p<0,05)$ entre as classes de tamanho dos bagos. Letras maiúsculas diferentes na coluna indicam diferenças significativas $(p<0,05)$ entre os tratamentos para a média de cada atributo. 
TABLE IV

Berry fresh weight, total soluble solids, $\mathrm{pH}$, titratable acidity, total phenolic index and anthocyanins concentration in different sized berries (A, B, $\mathrm{C}$ and D) from the different treatments considered in the irrigation and crop level experiment of 2005. Adjusted means after using ${ }^{\circ}$ Brix as a covariate are shown between parentheses. Low, medium and high crop loads are abbreviated as L, M and H, respectively.

Peso fresco de bago, sólidos solúveis totais, $\mathrm{pH}$, acidez titulável, indice de fenóis totais e concentação de antocianinas em bagos de diferentes tamanhos $(A, B, C$ e D) de cada tratamento considerado no ensaio de irrigação e nível de carga de 2005. As médias ajustadas após o uso de Brix como covariável são apresentadas entre parênteses. Cargas baixa, media e alta são abreviadas como L, Me H, respectivamente.

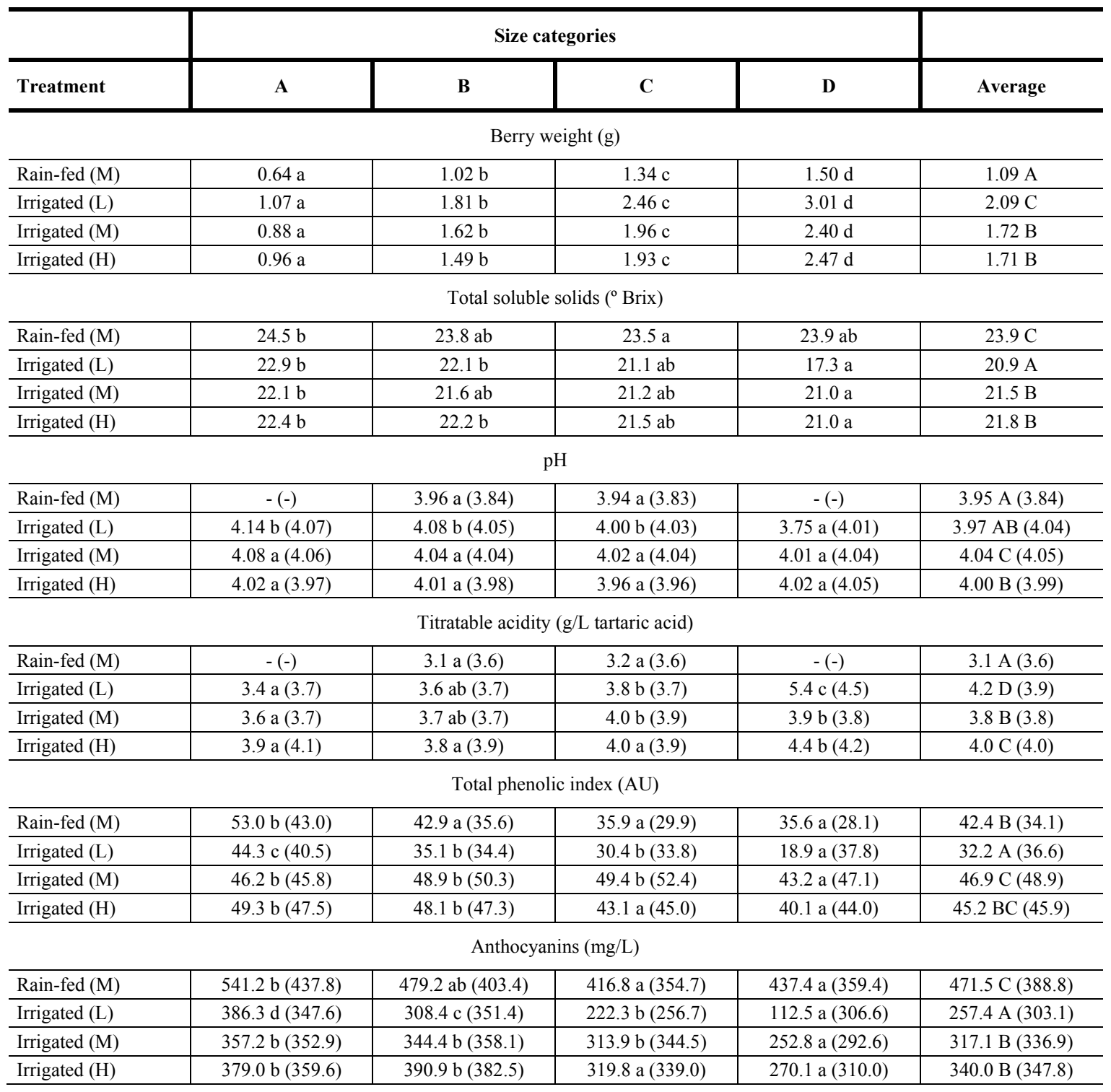

Different small letters in the row indicate significant differences $(p<0.05)$ among berry size classes. Different capital letters in the column indicate significant differences $(p<0.05)$ among treatments for the averaged attribute.

Letras minúsculas diferentes na linha indicam diferenças significativas $(p<0,05)$ entre as classes de tamanho dos bagos. Letras maiúsculas diferentes na coluna indicam diferenças significativas $(p<0,05)$ entre os tratamentos para a média de cada atributo.

Defoliation trial (2008):

In 2008, TSS significantly decreased with berry size for all the studied treatments (Table V). Titratable acidity significantly increased with berry size for ED, but decreased for $\mathrm{LD}$, whereas $\mathrm{pH}$ did not follow a clear pattern with berry size (Table V). Moreover, TPI and anthocyanins decreased with berry size when defoliation treatments were imposed (Table V). 


\section{TABLE V}

Berry fresh weight, total soluble solids, $\mathrm{pH}$, titratable acidity, total phenolic index and anthocyanins concentration in different sized berries (A, B, $\mathrm{C}$ and D) from the different treatments considered in the defoliation experiment of 2008 . Adjusted means after using ${ }^{\circ}$ Brix as a covariate are shown between parentheses. ED = early defoliation; $\mathrm{LD}=$ late defoliation; EED = early defoliation on the east side of the vine rows.

Peso fresco de bago, sólidos solúveis totais, pH, acidez titulável, índice de fenóis totais e concentação de antocianinas em bagos de diferentes tamanhos $(A, B, C$ e D) de cada tratamento considerado no ensaio de desfolhamento de 2008. As médias ajustadas após o uso de Brix como covariável são apresentadas entre parênteses. $E D=$ desfolhamento precoce; $L D=$ desfolhamento tardio; $E E D=$ desfolhamento precoce no lado leste das linhas de videira.

\begin{tabular}{|c|c|c|c|c|c|}
\hline Treatment & $\mathbf{A}$ & B & $\mathbf{C}$ & D & Average \\
\hline \multicolumn{6}{|c|}{ Berry weight (g) } \\
\hline Control & $1.23 \mathrm{a}$ & $1.85 \mathrm{~b}$ & $2.42 \mathrm{c}$ & $2.95 \mathrm{~d}$ & $2.11 \mathrm{~A}$ \\
\hline EED & $1.33 \mathrm{a}$ & $1.93 \mathrm{~b}$ & $2.37 \mathrm{c}$ & $3.13 \mathrm{~d}$ & $2.19 \mathrm{BC}$ \\
\hline \multicolumn{6}{|c|}{ Total soluble solids ( ${ }^{\circ}$ Brix) } \\
\hline Control & $21.1 \mathrm{a}$ & $21.1 \mathrm{a}$ & $20.1 \mathrm{a}$ & $19.7 \mathrm{a}$ & $20.5 \mathrm{~A}$ \\
\hline ED & $22.4 \mathrm{~b}$ & $21.8 \mathrm{ab}$ & $20.7 \mathrm{ab}$ & $20.3 \mathrm{a}$ & $21.3 \mathrm{~B}$ \\
\hline \multicolumn{6}{|c|}{$\mathrm{pH}$} \\
\hline Control & $3.80 \mathrm{a}(3.80)$ & $3.78 \mathrm{a}(3.78)$ & $3.79 \mathrm{a}(3.81)$ & $3.80 \mathrm{a}(3.84)$ & $3.79 \mathrm{BC}(3.81)$ \\
\hline ED & $3.79 \mathrm{a}(3.76)$ & $3.80 \mathrm{a}(3.79)$ & $3.75 \mathrm{a}(3.76)$ & $3.72 \mathrm{a}(3.74)$ & $3.76 \mathrm{AB}(3.76)$ \\
\hline LD & $3.86 \mathrm{~b}(3.79)$ & $3.80 \mathrm{ab}(3.78)$ & $3.77 \mathrm{a}(3.77)$ & $3.83 \mathrm{ab}(3.83)$ & $3.81 \mathrm{C}(3.79)$ \\
\hline EED & $3.77 \mathrm{a}(3.75)$ & $3.75 \mathrm{a}(3.74)$ & $3.74 \mathrm{a}(3.75)$ & $3.77 \mathrm{a}(3.79)$ & 3.76 A (3.76) \\
\hline \multicolumn{6}{|c|}{ Titratable acidity (g/L tartaric acid) } \\
\hline Control & $4.0 \mathrm{a}(4.0)$ & $4.1 \mathrm{a}(4.1)$ & $4.0 \mathrm{a}(4.0)$ & $4.0 \mathrm{a}(4.0)$ & $4.0 \mathrm{AB}(4.0)$ \\
\hline ED & $3.7 \mathrm{a}(3.7)$ & $3.7 \mathrm{a}(3.7)$ & $4.0 \mathrm{ab}(4.0)$ & $4.4 \mathrm{~b}(4.4)$ & 3.9 A (3.9) \\
\hline LD & $4.1 \mathrm{a}(4.0)$ & $3.9 \mathrm{a}(3.9)$ & $3.9 \mathrm{a}(3.9)$ & $3.7 \mathrm{a}(3.7)$ & 3.9 A (3.9) \\
\hline EED & $39.7 \mathrm{a}(54.2)$ & $35.9 \mathrm{a}(36.5)$ & $30.9 \mathrm{a}(22.9)$ & $17.9 \mathrm{a}(5.0)$ & $31.1 \mathrm{~A}(29.8)$ \\
\hline \multicolumn{6}{|c|}{ Anthocyanins (mg/g) } \\
\hline Control & $1.0 \mathrm{a}(1.0)$ & $1.3 \mathrm{a}(1.3)$ & $1.2 \mathrm{a}(1.0)$ & $1.1 \mathrm{a}(0.8)$ & $1.2 \mathrm{~A}(1.0)$ \\
\hline ED & $1.7 \mathrm{a}(1.9)$ & $1.4 \mathrm{a}(1.5)$ & $1.2 \mathrm{a}(1.1)$ & $1.2 \mathrm{a}(1.0)$ & $1.4 \mathrm{~A}(1.4)$ \\
\hline LD & $1.6 \mathrm{a}(2.2)$ & $1.4 \mathrm{a}(1.5)$ & $1.2 \mathrm{a}(1.2)$ & $1.1 \mathrm{a}(1.1)$ & $1.3 \mathrm{~A}(1.5)$ \\
\hline EED & $1.4 \mathrm{a}(1.6)$ & $1.3 \mathrm{a}(1.3)$ & $1.2 \mathrm{a}(1.1)$ & $1.0 \mathrm{a}(0.7)$ & $1.2 \mathrm{~A}(1.2)$ \\
\hline
\end{tabular}

Different small letters in the row indicate significant differences $(p<0.05)$ among berry size classes. Different capital letters in the column indicate significant differences $(p<0.05)$ among treatments for the averaged attribute.

Letras minúsculas diferentes na linha indicam diferenças significativas $(p<0,05)$ entre as classes de tamanho dos bagos. Letras maiúsculas diferentes na coluna indicam diferenças significativas $(p<0,05)$ entre os tratamentos para a média de cada atributo. 


\section{Relationships between berry size and berry composition}

Although there was a clear trend to lower TSS with increasing berry size in all treatments from all the experiments (Figure 2), these trends were not always significant. For instance, in 2004 the relationship between TSS and berry size was not significant for the high load treatment, whereas it was for the other treatments ( $\mathrm{R}^{2}$ between 0.95 and 0.99). In 2005, significant correlations were detected only for the irrigated treatments with medium and high loads.
Finally, in 2008, the only non-significant correlation was observed for LD. In 2004, the decreasing rate was rather similar between treatments (Figure 2a), although slightly more pronounced for the low crop load when compared to the rain-fed treatment. In 2005, the decreasing trend in TSS with increasing berry size was slightly higher for the irrigated treatment with high load (Figure 2b). In 2008, the declining rate was lower for the undefoliated control than for the other treatments (Figure 2c).

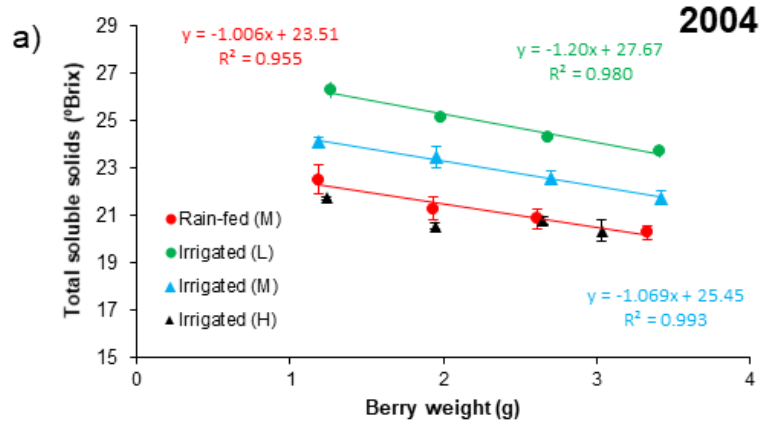

b)

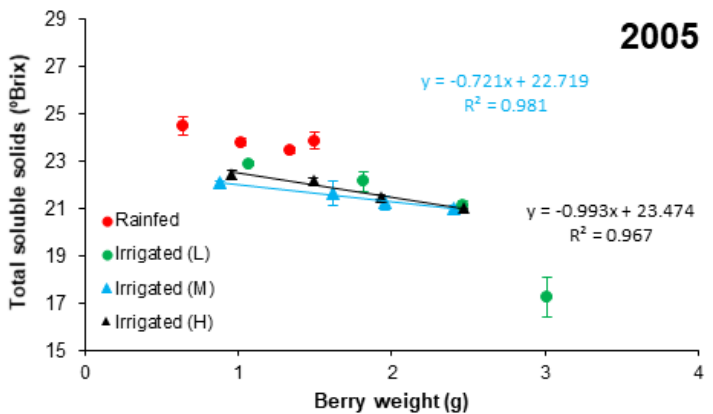

c)

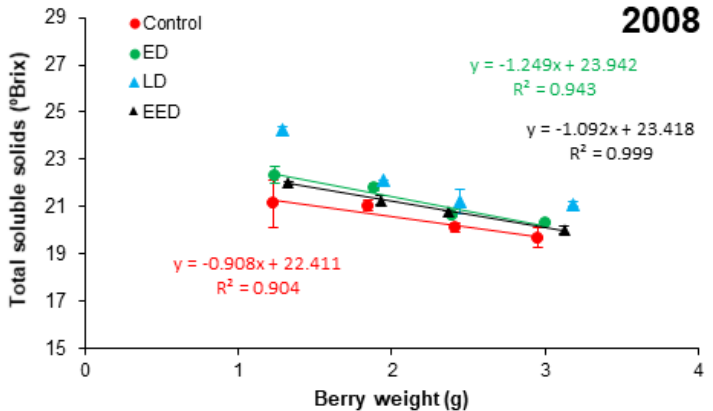

Figure 2. Total soluble solids in four different berry size categories from 'Tempranillo' grapes exposed to different treatments during the 2004 (a), 2005 (b) and 2008 (c) growing seasons. The linear regression lines and equations between total soluble solids and the average berry weight for each category and treatment are shown. Only significant regressions are depicted. $\mathrm{L}=$ low crop load; $\mathrm{M}=$ medium crop load; $\mathrm{H}=\mathrm{high}$ crop load; $\mathrm{ED}=$ early defoliation; $\mathrm{LD}=$ late defoliation; $\mathrm{EED}=$ early defoliation on the east side. Bars indicate standard errors $(\mathrm{n}=4)$.

Sólidos solúveis totais em quatro categorias diferentes de tamanho de bagos de uva de 'Tempranillo' expostos a diferentes tratamentos durante as vindimas de 2004 (a), 2005 (b) e 2008 (c). As linhas de regressão linear e as equações entre sólidos solúveis totais e peso médio dos bagos para cada categoria e tratamento são apresentadas. Apenas regressões significativas são mostradas. $L=$ carga baixa; $M=$ carga média; $H=$ carga alta; $E D=$ desfoliação precoce $; L D=$ desfoliação tardia; $E E D=$ desfoliação precoce no lado leste. Barras de erro indicam erros padrão $(n=$ 
Figure 3 shows the variations of TPI and anthocyanins with berry size for the experiment performed in 2005 as an example. In this case, TPI reduced significantly with berry size in all treatments, except for the irrigated vines with a medium crop load (Figure 3a). Anthocyanins concentration decreased with berry size in the rain-fed and the irrigated treatment with low crop load (Figure 3b). Regression coefficients ranged from 0.89 to 0.98 .
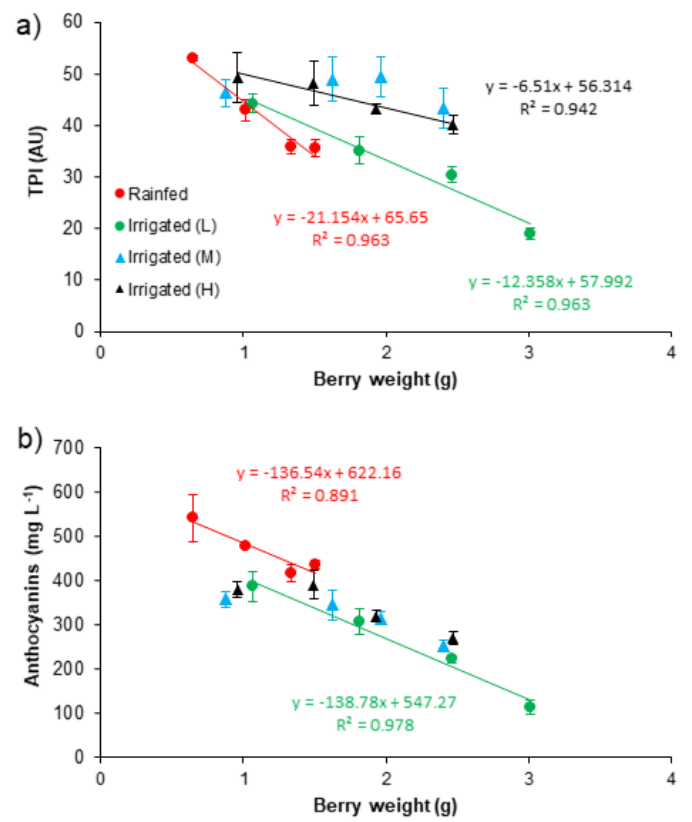

Figure 3. Total phenolic index (a) and concentration of anthocyanins (b) in four different size categories from 'Tempranillo' vines exposed to different treatments during the 2005 growing season. Linear regression lines and equations between the average values determined for the different parameters in each category against its average berry weight for each treatment are also shown. Only significant regressions are depicted. Bars indicate standard errors $(n=4)$. $L=$ low crop load; $M=$ medium crop load; $\mathrm{H}=$ high crop load.

Índice de fenóis totais (a) e concentração de antocianinas (b) em quatro diferentes categorias de tamanho de bagos de uva de

'Tempranillo' expostos a diferentes tratamentos durante a vindima de 2005. São mostradas as linhas de regressão linear e as equações entre os valores médios determinados para os diferentes parâmetros em cada categoria em relação ao seu peso médio de bagos para cada tratamento. Só se mostram as linhas de regressão significativas. Barras de erro indicam erros padrão $(n=4) . L=$ carga baixa; $M=$ carga média; $H=$ carga alta.

'Tempranillo' berry size followed a normal distribution, similarly to the findings from other studies (Shellie, 2010; Calderon-Orellana et al., 2014). However, this distribution was not observed in 2008 under the defoliated treatments, likely because of the modification in the source-sink ratio of the vines and, maybe, reducing the assimilate supply for the clusters. Berry size variation is established early in the first developmental stages of grapevine (Gray and Coombe, 2009). However, the treatments imposed here exerted a significant influence on berry size distribution since they varied the proportion of berries within each size class in all years. Our results suggest that high load and rain-fed treatments posed limitations to berry growth; in the case of the rain-fed treatment due to the effect of water stress, whereas in the high-load treatment, the limitation in berry growth was caused by a greater competition for the photoassimilates (Hunter and Ruffner, 2001). A similar behavior in relation to water stress was previously observed in Cabernet Sauvignon, where berries coming from a deficit-irrigated treatment showed smaller sizes than those from medium and highly irrigated treatments (Roby and Matthews, 2004). In accordance with our results, a recent study on Cabernet franc showed that water stress was the factor that affected largely fresh berry mass, sugar content and malic acid concentration (Triolo et al., 2018).

As previously found for Cabernet Sauvignon and Shiraz (Roby and Matthews, 2004; Walker et al., 2005; Calderon-Orellana et al., 2014), flesh and skin growth for 'Tempranillo' appeared to be coordinated since skin weight significantly increased with berry size both in 2004 and 2005. Independently of the treatment, seed number and weight increased with berry size, as previously reported for Cabernet Sauvignon and Merlot (Roby and Matthews, 2004; Shellie, 2010; Calderon-Orellana et al., 2014; Gil et al., 2015). These differences in seed weight might be relevant for tannin concentrations in wines because seeds and skins are the most important sources of tannins in red wines (Harbertson et al., 2003).

Sugar concentration in grapes plays a major role in shaping its sensory properties, determining alcohol content after fermentation, and providing precursors for the synthesis of aroma compounds (Dai et al., 2011). Total soluble solids concentration in the berries decreased with berry size independently of the treatment (irrigation, crop load or defoliation) imposed each year. Grapes from treatments involving some limitations (rain-fed, high crop load) showed a lower capacity for accumulating solutes. These results agree with previous reports for other varieties and indicate that berry size is not the only factor affecting sugar accumulation, but also environment and viticultural practices (Jackson and Lombard, 1993; Roby et al., 2004; Clingeleffer, 2010; van Leeuwen and Destric-Irvine, 2017; Triolo et al., 2018). However, it is relevant to notice the fact that the 
weather conditions occurring each year also altered the TSS concentrations in the grapes; for instance, the control treatment in 2005 (a dry year) showed a higher level of TSS than that of the control treatments in 2004 and 2008 .

In contrast to TSS, we did not detect a clear relationship between titratable acidity and berry size in any of the studied years due to the significant effect that treatments exerted on maturation. The concentration of organic acids in berries is influenced by those environmental parameters or viticultural practices that affect source-sink relationships and cluster microclimate (Jackson and Lombard, 1993), as crop load and irrigation in our study. The apparent incoherence observed for the effect of the early and late defoliation on berry acidity might have occurred because each defoliation treatment modified the cluster microclimate differently, altering the concentrations of the main organic acids in the berries (Risco et al., 2014). As for the year effect, similarly to the case of TSS, the control treatment in 2005 showed the lowest titratable acidity.

Phenolic attributes tended to decrease with berry size, although their values depended on the cultural practice imposed. In the case of TPI, high crop load caused significant reductions in their concentration for all berry sizes when compared to grapes from the other treatments, suggesting that photo-assimilate availability is a key factor controlling TPI synthesis. Irrigation treatments also diminished TPI content in berries; however, this reduction was not always significant in relation to the rain-fed control, in contrast with previous observations (Matthews and Anderson, 1988). In addition, early defoliation increased the TPI content of the berries, whereas the other defoliation treatments caused a decrease in TPI when compared to the undefoliated control.

Anthocyanins concentration clearly decreased with berry size in 'Tempranillo', as previously observed for other cultivars such as Cabernet Sauvignon and Shiraz (Roby et al., 2004; Walker et al., 2005). Cultural treatments and year exerted a significant effect on the anthocyanins concentration in 'Tempranillo' berries. For instance, in 2004, the high load treatment presented the lowest anthocyanins concentration for all berry sizes, indicating that photo-assimilate availability plays a major role on the synthesis of these compounds. Moreover, regulated deficit irrigation altered the concentrations of anthocyanins in 2004 and 2005, proving that this practice causes genetic changes in the expression of certain enzymes for most of the secondary metabolic pathways in Vitis vinifera, including those for anthocyanins synthesis (Castellarin et al., 2007;
Santesteban et al., 2011). In the case of the defoliation treatments imposed in 2008, our results suggest that the modifications of the light environment at the cluster zone altered anthocyanins synthesis in small berries.

The changes in berry composition over size reported here are in accordance with previous findings by other authors in different cultivars (Shellie, 2010; Calderon-Orellana et al., 2014; Gil et al., 2015). They support the hypothesis that berry mass per se is unlikely to be the main influence on the solute concentration in grapes and that the cultural treatments used to induce those small berries exert a major effect on berry composition (Roby et al., 2004; Roby and Matthews, 2004). The mechanisms by which water deficit, photo-assimilate availability or light exposure increased the concentrations of anthocyanins and soluble solids in the berries are probably the differential growth responses of skin and inner mesocarp tissue to these constraints (Roby and Matthews, 2004).

In view of these results, growers might try to control seasonal and within-vineyard variability and modulate berry size and composition through cultural practices (Harbertson et al., 2003). Depending on the objectives of the winery, growers may decide to favor small berries for increasing TSS and color attributes in order to obtain red wines with deep color, full body, soft tannin and fruity aromas, which are preferred nowadays for international markets (Gil et $a l ., 2015)$. In addition, they could use larger berries for entry-level wines after a process of berry classification. Nevertheless, our results proved that berry composition can be modulated through varying crop load, irrigation management and defoliation; and larger berries obtained under several of the treatments imposed possessed interesting oenological properties, hence, they could be used for achieving high-quality 'Tempranillo' wines under Mediterranean conditions. Further research is needed to understand the effects of other cultural practices and on other cultivars, as well as about the economic feasibility of these management practices (Clingeleffer, 2010).

Finally, winegrowers must consider that most of the berries would fit into the middle classes of the size distribution. Medium-size berries account for up to $80 \%$ of the total yield, whereas small berries only represent $10 \%$. Hence, the improvements in quality observed for small berries may not influence the total production of the vineyard and not be of economic importance. Cultural practices can be used for obtaining medium-size berries with optimal compositional attributes, as reported here. 


\section{CONCLUSIONS}

This study provided further evidence supporting the essential influence of agronomical practices on berry size and composition by analyzing separately the attributes of grapes from different sizes in a red grapevine cultivar widely grown in Spain. In our study, smaller berries had higher sugar and anthocyanins concentrations than larger berries. However, irrigation, crop load and defoliation affected these compositional traits, producing greater berries with similar traits than those smaller but coming from rain-fed and not defoliated treatments, suggesting that grape composition, for a given berry

\section{REFERENCES}

Allen, R.G., Pereira, L.S., Raes, D., Smith, M., 1998. Crop evapotranspiration. Guidelines for computing crop cater requirements. FAO Irrigation and Drainage paper No 56, Rome, Italy.

Barbagallo, M.G., Guidoni S., Hunter J.J., 2011. Berry size and qualitative characteristics of Vitis vinifera L. cv. Syrah. S. Afr. J. Enol. Vitic., 32, 129-136.

Bock, A., Sparks, T.H., Estrella, N., Menzel, A., 2013. Climateinduced changes in grapevine yield and must sugar content in Franconia (Germany) between 1805 and 2010. PLoS One, 8 (7), e69015.

Calderon-Orellana A., Matthews M.A., Drayton W.M., Shackel K.A., 2014. Uniformity of ripeness and size in Cabernet Sauvignon berries from vineyards with contrasting crop price. Am. J. Enol. Vitic., 65, 81-88.

Castellarin S.D., Pfeiffer A., Sivilotti P., Degan M., Peterlunger E., Di Gaspero G., 2007. Transcriptional regulation of anthocyanin biosynthesis in ripening fruits of grapevine under seasonal water deficit. Plant Cell Environ., 30, 1381-1399.

Clingeleffer P.R., 2010. Plant management research: status and what it can offer to address challenges and limitations. Aust. J. Grape Wine Res., 16, 25-32.

Dai Z.W., Ollat N., Gomès E., Decroocq S., Tandonnet J-P., Bordenave L., Pieri P., Hilbert G., Kappel C., van Leeuwen C., Vivin P., Delrot S., 2011. Ecophysiological, genetic, and molecular causes of variation in grape berry weight and composition: a review. Am. J. Enol. Vitic., 62, 413-425.

Fraga, H., García de Cortázar Atauri, I., Malheiro, A.C., Santos, J.A., 2016. Modelling climate change impacts on viticultural yield, phenology and stress conditions. Global Change Biol., 22, 37743788

Gil M., Pascual O., Gómez-Alonso S., García-Romero E., Hermosín-Gutiérrez I., Zamora F., Canals J.M., 2015. Influence of berry size on red wine colour and composition. Aust. J. Grape Wine Res., 21, 200-212.

Gray J., Coombe B.G., 2009. Variation in Shiraz berry size originates before fruitset but harvest is a point of resynchronization for berry development after flowering. Aust. J. Grape Wine Res., 15, 156-165.

Harbertson J.F., Picciotto E.A., Adams D.O., 2003. Measurement of polymeric pigments in grape berry extracts and wines using a size, can be modulated through agricultural practices. Therefore, wineries can sort berries for selecting those from a given size and agricultural treatment in order to make different wine styles.

\section{ACKNOWLEDGMENTS}

This work was supported by the Spanish Ministry of Economy and Competitiveness MINECO, cofinanced by FEDER [grant numbers AGL201454201-C4-4-R and AGL2017-83738-C3-3-R].

protein precipitation assay combined with bisulfite bleaching. $\mathrm{Am}$ J. Enol. Vitic., 54, 301-306.

Holt H.E., Francis I.L., Field J., Herderich M.J., Iland P.G., 2008. Relationships between berry size, berry phenolic composition and wine quality scores for Cabernet Sauvignon (Vitis vinifera L.) from different pruning treatments and different vintages. Aust. J. Grape Wine Res., 14, 191-202.

Houel C., Martin-Magniette M.L., Nicolas S.D., Lacombe T., Le Cunff L., Franck D., Torregrosa L., Conéjéro G., Lalet S., This P., Adam-Blondon A.F., 2013. Genetic variability of berry size in the grapevine (Vitis vinifera L.). Aust. J. Grape Wine Res., 19, 208220

Hunter J.J., Ruffner H.P., 2001. Assimilate transport in grapevines - effect of phloem disruption. Aust. J. Grape Wine Res., 7, 118126

Iland P., Bruer N., Edwards G., Weeks S., Wilkes E., 2004. Chemical Analysis of Grapes and Wine: Techniques and Concepts. 120 p. Patrick Iland Wine Promotions, Campelltown.

Intrigliolo D.S., Castel J.R., 2008. Effects of irrigation on the performance of grapevine cv. Tempranillo in Requena, Spain. Am. J. Enol. Vitic., 59, 30-38.

Intrigliolo D.S., Castel J.R., 2011. Interactive effects of deficit irrigation and shoot and cluster thinning on grapevine $\mathrm{cv}$. Tempranillo. Water relations, vine performance and berry and wine composition. Irrig. Sci., 29, 443-454.

IPCC, 2014. Climate Change 2014: Impacts, adaptation, and vulnerability. Part A: Global and sectoral aspects. Contribution of working group II to the fifth assessment report of the Intergovernmental Panel on Climate Change [Field, C.B., V.R. Barros, D.J. Dokken, K.J. Mach, M.D. Mastrandrea, T.E. Bilir, M. Chatterjee, K.L. Ebi, Y.O. Estrada, R.C. Genova, B. Girma, E.S. Kissel, A.N. Levy, S. MacCracken, P.R. Mastrandrea, and L.L.White (eds.)]. 1132 p. Cambridge University Press, Cambridge.

Jackson D.I., Lombard P.B., 1993. Environmental and management practices affecting grape composition and wine quality - A review. Am. J. Enol. Vitic., 44, 409-430.

Keller, M., 2010. The science of grapevines: Anatomy and physiology. 400 p. Elsevier, Amsterdam.

Matthews M.A., Anderson M.M., 1988. Fruit ripening in Vitis vinifera L.: responses to seasonal water deficits. Am. J. Enol. Vitic., 39, 313-320.

Matthews M.A., Nuzzo V., 2007. Berry size and yield paradigms on grapes and wines quality. Acta Hortic., 754, 423-436. 
Ribereau-Gayon P., Glories Y., Maujean A., Dubourdieu D., 2000. Phenolic compounds, In: Handbook of Enology, Vol. 2 - The Chemistry of Wine Stabilization and Treatment. 129-187. RibereauGayon, P., Glories, Y., Maujean, A., Dubourdieu, D. (eds.), John Wiley \& Sons, New York

Risco D., Pérez D., Yeves A., Castel J.R., Intrigliolo D.S., 2014. Early defoliation in a temperate warm and semi-arid Tempranillo vineyard: vine performance and grape composition. Aust. J. Grape Wine Res., 20, 111-122.

Robinson, A.L., Boss, P.K., Solomon, P.S., Trengove, R.D., Heymann, H., Ebeler, S.E., 2014. Origins of grape and wine aroma. Part 1. Chemical components and viticultural impacts. Am. J. Enol. Vitic., 65, 1-24.

Roby G., Harbertson J.F., Adams D.A., Matthews M.A., 2004. Berry size and vine water deficits as factors in winegrape composition: anthocyanins and tannins. Aust. J. Grape Wine Res., 10, 100-107.

Roby G., Matthews M.A., 2004. Relative proportions of seed, skin and flesh, in ripe berries from Cabernet Sauvignon grapevines grown in a vineyard either well irrigated or under water deficit. Aust. J. Grape Wine Res., 10, 74-82.

Santesteban L.G., Miranda C., Royo J.B., 2011. Regulated deficit irrigation effects on growth, yield, grape quality and individual anthocyanin composition in Vitis vinifera L. cv. 'Tempranillo'. Agric. Water Manage., 98, 1171-1179.
Shellie K.C., 2010. Water deficit effect on ratio of seed to berry fresh weight and berry weight uniformity in winegrape cv. Merlot. Am. J. Enol. Vitic., 61, 414-418.

Simonneau, T., Lebon, E., Coupel-Ledru, A., Marguerit, E., Rossdeustch, L., Ollat, N., 2017. Adapting plant material to face water stress in vineyards: which physiological targets for an optimal control of plant water status? OENO One, 51, 167-169.

Singleton V.L., 1972. Effects on red wine quality of removing juice before fermentation to simulate variation in berry size. Am. J. Enol. Vitic., 23, 106-113.

Triolo, R., Roby, J.P., Plaia, A., Hilbert, G., Buscemi, S., D Lorenzo, R., van Leeuwen, C., 2018. Hierarchy of factors impacting grape berry mass: separation of direct and indirect effects on major berry metabolites. Am. J. Enol. Vitic., 69, 103-112.

van Leeuwen, C., Destrac-Irvine, A., 2017. Modified grape composition under climate change conditions requires adaptations in the vineyard. OENO One, 57, 147-154.

Walker R.R., Blackmore D.H., Clingeleffer P.R., Kerridge G.H., Rühl E.H., Nicholas P.R., 2005. Shiraz berry size in relation to seed number and implications for juice and wine composition. Aust. J. Grape Wine Res., 11, 2-8.

Xie, S., Tang, Y., Wang, P., Song, C., Duan, B., Zhang, Z., Meng, J., 2018. Influence of natural variation in berry size on the volatile profiles of Vitis vinifera L. cv. Merlot and Cabernet Gernischt grapes. PLoS One, 13, e0201374. 